\title{
Unification of Economic Systems in the Global Economy: Barriers and Preconditions
}

\author{
Svetlana G. Vokina', Yulia S. Zima ${ }^{2}$, Nikolai G. Sinyavsky ${ }^{3,4}$, Vadim Meshkov ${ }^{5}$, Aleksandra V. Sultanova ${ }^{6}$
}

\begin{abstract}
The purpose of the article is to determine barriers and preconditions for reducing the differences in the level of development in the global economy's countries and to develop recommendations for solving the problem of the global economy's economic systems unification.

In order to determine the gap between developed and developing countries, the authors use the comparative analysis method. In order to determine possibilities, problems, perspectives, and threats to overcoming the gap by developing countries, the authors use the SWOT-analysis method. For studying the global economy's economic development disproportions, this research uses specially developed proprietary analysis of gap depth in economic development.

As a result of the analysis, the authors determined that the level of economic development of the most developed countries exceeds the level of developing countries by more than four times. This reflects a huge gap depth and a high level of differentiation for countries in the global economy.

The authors conclude that barriers of unification of economic systems in the global economy are primarily related to socio-political factors. Preconditions to reducing the difference in level of economic development for countries in the global economy are predetermined by the influence of globalization and international integration of economic systems.
\end{abstract}

KEY WORDS: Problem of Unification, Economic System, Global Economy, Economic Development Disproportions

JEL Classification: F63

${ }^{1}$ Plekhanov Russian University of Economics, Russia; ${ }^{2}$ Rostov State Economic University, Russia; ${ }^{3}$ Volgograd State Agricultural University, Russia; ${ }^{4}$ Financial University under the Government of the Russian Federation, Russia; ${ }^{5}$ Perm Institute of Economics and Finance, Russia; ${ }^{6}$ Samara State Technical University, Russia

\section{Introduction}

It is difficult to overestimate the actuality of the studying the problem of unification of economic system.

The global economy's change in polarity after the

Correspondence concerning this article should be addressed to: Svetlana G. Vokina, Department of Information Technology of Plekhanov Russian University of Economics, 36 Stremyanny Ln., Moscow 117997, Russia. E-mail: svetlana-voki@rambler.ru breakup of the Soviet Union increased the gap between Northern American and Central European developed countries and the rest of the world, i.e., a large group of African and post-Soviet developing countries.

Among developing countries, there are many economic systems that develop very quickly and create separate categories of countries, including NIC, BRICS, etc. They cannot be considered to be developed countries yet, but in the near future they can reach this 
level or even exceed it. These countries are the most perspective players in the system of modern international economic relations, and their economic state is the most predictable.

At a first glance, it may seem that such structure of the global economy is normal. In macro-economic research, the system that is built according to the pyramid principle (with a massive foundation from the least secured groups of the population at the bottom, a narrower middle part comprised of a population with medium welfare, and small top represented by the elite of a society with the highest level of income) is, as a rule, considered to be the model.

Stability of the macro-economic pyramid is ensured by means of low socio-economic mobility of population and high level of securing a social position with various categories of economic subjects. However, on a global scale, social lift works faster because with the reduction of living standards, citizens of the least developed countries strive into developed countries, which strengthens migration flows.

As a result, developing countries lose their most valuable human resources, which required state budget assets to develop. This loss reduces their capability for economic development. On the other hand, developed countries receive a lot of refugees without money and knowledge of the language, which increases the size of the population of marginal groups and reduces the population's living standards.

The concept of economic development does not presume reducing the developed countries' living standards, which will lead to stagnation of the global economy, but increase of living standards in developing countries for overcoming the gap between these categories of countries and achieving relatively even global economic growth. On the one hand, developed countries are interested in keeping their competitive positions and preserving their advantage of an elite position in the global economy. On the other hand, mass migration negatively influences their economic development and motivates them to support developing countries.

Despite the gravity of the global economic system's situation and the necessity for a solution, which all members of international economy realize, there are no working methods for overcoming the growing gap between developed and developing countries. The pur- pose of this article is to determine barriers and preconditions to reducing the differences in the level of economic development in the global economy's countries and to develop recommendations for solving the problem of the global economy's economic systems unification.

\section{Literature review}

Many modern authors have studied and researched the issue of the global economy's economic disparity by analyzing economic systems' existing vectors and growth poles; determining the global economy's causes and consequences of unequal development; and comparing the economic systems' possibilities and conditions for development (Bhanumurthy \& Singh, 2013; Bozkurt, Erdem, \& Erollu, 2015; Caporale \& Spagnolo, 2012). The disproportions of economic development are a difference between the rate of economic growth and living standards in various countries (Gehringer, 2014). They emerge due to different geographical conditions and cultural traditions, a difference in methods of economic activities, and various approaches to conducting business, etc. (Jahfer \& Inoue, 2014). These disproportions negatively influence the most and the least developed countries (Al Mamun \& Sohag, 2015). There are ongoing studies analyzing the possibility for increasing the rate of economic growth and its qualitative transformation by reducing the expansion of exhaustible resources, and shutting down ecologically unsafe industrial produced, developed, and manufactured innovative products and services (González-Pernía \& Peña-Legazkue, 2015; Leonida, Patti, Marini, \& Navarra, 2015; Odhiambo, 2015; Pogosov, 2015; Popkova, Yurev, Stepicheva, \& Denisov, 2015b; Bartolini \& Sarracino, 2015; Zeira \& Zoabi, 2015; etc.).

Economic growth is one of the most important indicators of an economic system's development (Choi \& Shin, 2015). It reflects the volume of national production in dynamics and comparison with other countries of the world (Lee \& Oh, 2015). Economic growth is a method for overcoming the gap of the least economically developed countries (Castiglione, Infante, \& Smirnova, 2015)

Additionally, there is current research into the reasons for developed countries' domination in the global economic system; evolution of their formation, mov- 
ing forces, and conditions of their development today; peculiarities of state management, social specifics, and character of business activities and innovational activities; and the role of developed countries in activities of international organizations and efforts to reduce the gap between them and developing countries (Chechina \& Sultanova, 2016; Fan, Cui, Li, \& Zhu, 2015; Gevorkyan \& Semmler, 2015; Kandil, 2016; Sekine, 2015 etc.). In the modern global economy, the most developed countries are in Western Europe and the USA (Tsenkov, 2015) because their population's have the greatest inclination for implementating innovations and a high regard for the entrepreneurial spirit (Anderson, Sutherland, Severe, 2015).

Oddly, state management in the most developed countries stimulates free competition, which is considered to be a source of economic growth and development (Popkova, Abramov, \& Chechina, 2015a).

There is also research into the possibilities of developing countries' economic growth; reasons and perspectives of overcoming the gap between them; structure of their economic systems; level of their involvement in integration and globalizing processes in modern global economy; the relationship between state and business structures; methods for attracting investments; and approaches to diversifying an economy (Chen \& Chen, 2015; Dowlah, 2015; Dögl \& Behnam, 2015; Kuruppu \& Willie, 2015; Regmi, 2015). Many developing countries possess huge natural and human resources, which creates conditions for their successful development (Sarmiento Espinel, Silva Arias \& Van Gameren, 2015). However, the level of entrepreneurial and innovational activity in these countries is rather low (Dube \& Sivakumar, 2015). The state strives to realize protectionist policies and monopolize the economy in these countries (Jeníček \& Grofová, 2015).

Nevertheless, despite large interest in the problem of unification of economic systems in the global economy, its solution has not yet been found. This leaves a space for further research in this sphere that should not be theoretical, but rather applicable in nature. This research should also be aimed at searching for mechanisms to reduce the level of differentiation of economic development of various countries in the global economy and develop perspective models for activating developing countries' economic growth.

\section{Method}

In order to determine the gap between developed and developing countries, this paper uses the comparative analysis method. For determining possibilities, problems, perspectives, and threats to developing countries' overcoming the gap, the SWOT-analysis method is used. For studying the global economy's economic development disproportions, this research uses a specially developed proprietary method of analysis of gap depth in economic development.

Within this method, several of the most typical systems for each of three categories of countries (in this article, three countries of each category was selected in order to stay within the limits of the scientific article) are selected, and the most significant indicators of their economic development are viewed:

- growth rate of national GDP;

- structure of GDP;

- volume of investments into the economy;

- share of innovational products in structure of national production; and

- migration flows (number of emigrant and immigrants).

It is assumed that these indicators show the difference between developed and developing countries, and these indicators are accessible as reflected in international statistical data.

The selected methods are used to classify countries in the international economy. It is acknowledged that developed countries have a post-industrial GDP structure (domination of the service sphere), low rate of GDP growth, substantial volume of investments into the economy, high rate of innovational products, and positive migration flow (number of immigrants is higher than the number of emigrants).

Developing countries are characterized by industrial GDP structure (domination of industry), high growth rates of GDP, low share of innovational products, and positive migration flow (number of emigrants is larger than the number of immigrants). Large volumes of investments into the economy characterize the leading developing countries, and the underdeveloped countries are characterized by zero volume or even outflow of investments.

In the process of analysis of statistical information in the current state and dynamics of the given indica- 
tors, regularities peculiar for each of the selected category of countries are determined. On the basis of these regularities, the system of scales for three categories of countries is developed.

After that, the received values in scales are compared, and the ratio of the largest value to the smallest one is found, and depth of the gap between countries as to all indicators is determined. Finally, the economic disproportion index (EDI) is calculated as an average of all the indicators. Correspondingly, the larger the index means the stronger the level of disproportion of economic development of the global economy's countries.

\section{Results}

Using the developed proprietary method to study gap depth in economic development of developed as well as quickly and slowly developing countries, we will look at the developed countries of the USA, Norway, and Sweden; India, China, and the United Arab Emirates for the quickly developing countries; and Brazil, Russia, and South Africa for the slowly developing countries, which lag behind the most. These countries are selected based on their ranking of prosperity in the world in 2014 (Legatum Institute, 2015). Results of analysis of economic development of the selected countries are given in Tables 1-3.

Based on the data of Tables 1-3, it is possible to conclude that the highest rate of economic growth, more than $4 \%$ per year, is peculiar for quickly developing countries, which helped determine their name. Developed countries show an average national GDP rate of growth at $1.2 \%-4 \%$ per year. The slowly developing countries, which lag behind, show the smallest rate of growth at less than $1.2 \%$ per year.

In developed countries, the service sphere accounts for $65 \%-80 \%$ and determines their international production specialization, while quickly developing countries specialize in industrial production and their share of service sector accounts for $30 \%-45 \%$. The slowly developing countries, which lag behind, have increased their volume in the service sphere, but still cannot reach the level of developed countries.

Developed countries have the largest investment attractiveness, and the volume of investments into these countries constitutes more than $\$ 700$ billion. For example, in the USA, this indicator was $\$ 2,000$ billion in 2014. Developing countries are ranked second for in- vestment attractiveness, and they receive $\$ 300-700$ billion of investments annually. Underdeveloped countries pose less interest for investors and, as a result, this leads to a $\$ 300$ billion per year level of investments into these countries.

Share of innovational products in the structure of GDP of developed countries is the largest and constitutes more than 15\%; in quickly developing countries it constitutes $4-10 \%$; and it is less than $4 \%$ in underdeveloped countries. Developed countries received more than 10,000 immigrants annually, and less than 4,000 people emigrated. Quickly developing countries received 4,000-10,000 people annually, and more than 10,000 people emigrated.

This is due to the fact that quick level of development predetermines increase of birth rate of population, which leads to overpopulation. In underdeveloped countries, incoming migration flow constitutes less than 4,000 people annually, and outgoing flow comprised of 4,000-10,000 people. Based on this data, a combined table is compiled that reflects gap depth between different categories of countries for viewed indicators, (Table 4).

Calculation of economic disproportion index for the global economy in 2014 looks as follows: $\mathrm{EDI}=(4+5+7+7+3+3) / 6=4$. The received value of index shows that the level of economic development of the most developed countries exceeds the level of underdeveloped countries by more than four times. It shows huge gap depth and a high level of differentiation of the global economy's countries. The gap between developed and developing countries is shown in Table 5. The most important barriers of unification of economic systems in the global economy are the following:

- deep socio-cultural development, leading to different attitudes to business, different levels of perceiving innovations, etc.;

- orientation at overcoming the development path for the purpose of achieving the level of developed countries instead of searching for its own innovational economic development path;

- lack of investments for realizing innovational projects; and

- lack of stimuli for developing national production due to a policy of protectionism and low level of competition in a relatively closed national economy. 
Table 1. Analysis of economic development of developed countries

\begin{tabular}{lccc}
\hline \multirow{2}{*}{ Indicators } & \multicolumn{2}{c}{ Developed countries } \\
\cline { 2 - 4 } Growth rate of national GDP, $\%$ & USA & Norway & Switzerland \\
Share of industry/Share of service sphere in GDP & 2.4 & 1.8 & 1.3 \\
Volume of investments into economy, \$ billion & $20 / 80=0.25$ & $20 / 75=0.26$ & $34 / 65=0.52$ \\
Share of innovational products in structure of national production, $\%$ & 35 & 14 & 307 \\
Number of immigrants, thousand people & 45 & 0.7 & 9 \\
Number of emigrants, thousand people & 3 & 0.2 & 3 \\
\hline
\end{tabular}

Source: Adapted from "Ranking of countries as to the rates of growth of GDP in 2014" by NoNews (2015). Retrieved from http://nonews.co/directory/lists/countries/gdp-temp; "Ranking of countries as to volume of direct foreign investments in 2014", by Yes!travel (2015). Retrieved from http://www.yestravel.ru/world/rating/stock_of_direct_foreign_investment_at_home_rank_order/

Table 2. Analysis of economic development of quickly developing countries

\begin{tabular}{lccc}
\hline \multirow{2}{*}{ Indicators } & \multicolumn{2}{c}{ Quickly developing countries } \\
\cline { 2 - 4 } & India & China & UAE \\
\hline Growth rate of national GDP, $\%$ & 5.6 & 7.4 & 4.3 \\
Share of industry/Share of service sphere in GDP & $30 / 50=0.60$ & $45 / 45=1.00$ & $60 / 40=1.50$ \\
Volume of investments into economy, \$ billion & 96 & 759 & 44 \\
Share of innovational products in structure of national production, \% & 5 & 20 & 8 \\
Number of immigrants, thousand people & 5 & 14 & 0.8 \\
Number of emigrants, thousand people & 14 & 10 & 7 \\
\hline
\end{tabular}

Source: Adapted from "Ranking of countries as to the rates of growth of GDP in 2014" by NoNews (2015). Retrieved from http://nonews.co/directory/lists/countries/gdp-temp; "Ranking of countries as to volume of direct foreign investments in 2014", by Yes!travel (2015). Retrieved from http://www.yestravel.ru/world/rating/stock_of_direct_foreign_investment_at_home_rank_order/

Table 3. Analysis of economic development of underdeveloped countries

\begin{tabular}{lccc}
\hline \multirow{2}{*}{ Indicators } & \multicolumn{2}{c}{ Underdeveloped countries } \\
\cline { 2 - 4 } & Brazil & Russia & South Africa \\
\hline Growth rate of national GDP, $\%$ & 0.3 & 0.5 & 1.4 \\
Share of industry/Share of service sphere in GDP & $30 / 65=0.46$ & $30 / 60=0.46$ & $25 / 65=0.38$ \\
Volume of investments into economy, \$ billion & 248 & 272 & 93 \\
Share of innovational products in structure of national production, $\%$ & 4 & 3 & 2 \\
Number of immigrants, thousand people & 0.6 & 11 & 11 \\
Number of emigrants, thousand people & 1.7 & 2014 by & 2 \\
\hline
\end{tabular}

Source: Adapted from "Ranking of countries as to the rates of growth of GDP in 2014"by NoNews (2015). Retrieved from http://nonews.co/directory/lists/countries/gdp-temp; "Ranking of countries as to volume of direct foreign investments in 2014", by Yes!travel (2015). Retrieved from http://www.yestravel.ru/world/rating/stock_of_direct_foreign_investment_at_home_rank_order/ 
Table 4. Combined table for determining the gap between levels of economic development of countries from different categories

\begin{tabular}{lcccc}
\hline \multirow{2}{*}{ Indicators } & \multicolumn{3}{c}{ Countries } \\
\cline { 2 - 4 } & Developed & $\begin{array}{c}\text { Quickly } \\
\text { developing }\end{array}$ & Underdeveloped \\
\hline Growth rate of national GDP, \% & $1.2-4$ & $>4$ & $<1.2$ & 4 \\
Share of industry/Share of service sphere in GDP & $0.25-0.37$ & $0.50-1.00$ & $0.38-0.49$ & 5 \\
Volume of investments into economy, \$ billion & $>700$ & $300-700$ & $<300$ & 7 \\
Share of innovational products in structure of national production, \% & $>15$ & $4-15$ & $<4$ & 3 \\
Number of immigrants, thousand people & $>10$ & $4-10$ & $<4$ & 3 \\
Number of emigrants, thousand people & $<4$ & $>10$ & $4-10$ & 3 \\
\hline
\end{tabular}

Source: Adapted from "Ranking of countries as to the rates of growth of GDP in 2014" by NoNews (2015). Retrieved from http://nonews.co/directory/lists/countries/gdp-temp; "Ranking of countries as to volume of direct foreign investments in 2014", by Yes!travel (2015). Retrieved from http://www.yestravel.ru/world/rating/stock_of_direct_foreign_investment_at_home_rank_order/

Table 5. Gap between developed and developing countries

\begin{tabular}{|c|c|c|}
\hline Criterion of comparison & Developed countries & Developing countries \\
\hline Leading sphere of economy & Service sphere & Industry \\
\hline Role in industrial production process & $\begin{array}{c}\text { Development of production, } \\
\text { creation of technologies, production } \\
\text { management }\end{array}$ & $\begin{array}{l}\text { Direct manufacture of industrial } \\
\text { products }\end{array}$ \\
\hline $\begin{array}{l}\text { Production factors based on an } \\
\text { economy's functioning }\end{array}$ & $\begin{array}{l}\text { Human capital, investment resources, } \\
\text { entrepreneurial capability }\end{array}$ & $\begin{array}{l}\text { Cheap workforce, cheap and } \\
\text { abundant natural resources }\end{array}$ \\
\hline $\begin{array}{l}\text { Level of development of institutional } \\
\text { and infrastructural basis }\end{array}$ & $\begin{array}{l}\text { Advanced institutions and } \\
\text { infrastructure }\end{array}$ & $\begin{array}{l}\text { Underdeveloped institutions and } \\
\text { infrastruce }\end{array}$ \\
\hline $\begin{array}{l}\text { Level of investment attractiveness of } \\
\text { an economy }\end{array}$ & $\begin{array}{l}\text { High level of investment } \\
\text { attractiveness of an economy }\end{array}$ & $\begin{array}{l}\text { Low level of investment } \\
\text { attractiveness of an economy }\end{array}$ \\
\hline
\end{tabular}

Preconditions for reducing the level of economic development differentiation of the global economy's countries are the following:

- reduction of socio-cultural differences and transition to the policy of free-trading in the process of globalization;

- announcement of the course for building an innovation-oriented economy in developing countries; and
- strengthening capital flow from developed countries into developing ones under the influence of integration processes in the global economy.

Recommendations for solving the issue of unification of economic systems in the global economy are the following:

- development of the population's competencies through changing the existing educational pro- 
Table 6. SWOT-analysis results for overcoming developing countries' underperformance

\begin{tabular}{|c|c|}
\hline $\begin{array}{l}\text { Capabilities of developing countries in the sphere of } \\
\text { economic growth }\end{array}$ & $\begin{array}{l}\text { Problems of economic growth of developing } \\
\text { countries }\end{array}$ \\
\hline Availability of accessible natural resources & Society's inadaptability for market conditions of economy \\
\hline Cheap workforce & Lack of investment resources \\
\hline Unexhausted potential for development & Low-competitive business environment \\
\hline $\begin{array}{l}\text { Perspectives of overcoming the developing countries' } \\
\text { underperformance }\end{array}$ & $\begin{array}{l}\text { Threats to overcoming developing countries' } \\
\text { underperformance }\end{array}$ \\
\hline $\begin{array}{l}\text { Social changes under the influence of globalization of the } \\
\text { world economy }\end{array}$ & $\begin{array}{l}\text { Termination of social adaptation due to reducing process } \\
\text { integration }\end{array}$ \\
\hline $\begin{array}{l}\text { Attraction of investments by means of creating a favorable } \\
\text { investment climate }\end{array}$ & $\begin{array}{l}\text { Inefficiency of measures to increase investment } \\
\text { attractiveness }\end{array}$ \\
\hline Development of business as a result of state support & $\begin{array}{l}\text { Without support and market stimuli, business will not } \\
\text { develop }\end{array}$ \\
\hline
\end{tabular}

grams and under the conditions of an innovationoriented market economy;

- stimulation of development of innovational business through a simplified system of business registration, financial accounting and state financing for creating innovational startups; and

- creation of a favorable tax regime and provision of state guarantees for investors to attract foreign investments in order to realize innovational projects in developing countries.

Table 6. shows how the SWOT-analysis results demonstrate the developing countries' underperformance and how they can overcome it by realizing the given tendencies

\section{Conclusion}

As a result of comparative analysis of economic development of developed countries, quickly developing countries, and underdeveloped countries, it was determined that the countries' level of development in the various categories differs by four times, which demonstrates a high differentiation of economic systems in the global economy.
The gap between developed and developing countries consists in their differences in their roles in the production process. Developed countries create technologies and produce management. On the other hand, developing countries are involved in the direct manufacture of industrial production and, as a result, take ecological risks and environmental losses by placing hazardous industries on the territory.

The developed countries' economy functions thanks to human capital, investment resources, and business capabilities; whereas, developing countries' economy is based on a cheap workforce and natural resources. Moreover, the developed countries have advanced institutions and infrastructure as well as are attractive for investments but developing countries are not as attractive for investments.

Barriers for unification of economic systems in the global economy are primarily caused by socio-political factors. The influence of globalization and the international integration of economic systems will help reduce the differentiation of the level of economic development of the global economy's countries. In order to resolve the issue of economic systems unification in the global economy, developing countries must acti- 
vate their market processes, stimulate business development, and attract foreign investments.

As the results of the SWOT-analysis in overcoming the developing countries' underperforance demonstrate, the most important means of solving the problem of the global economy's economic systems unification is to institute effective state policies and develop their internal potential to create and grow innovative businesses.

The conducted research's results are limited by the reviewed criteria and countries selected for comparative analysis in the various categories, which could be a reason for not determining all of the peculiarities for developed, quickly developing, and underdeveloped countries. Further research may be developed by conducting a more complex and systemic analysis of the disproportions of the global economy's development.

\section{References}

Al Mamun, M., \& Sohag, K. (2015). Revisiting the dynamic effect of foreign direct investment on economic growth in LDCs. International Journal of Economic Policy in Emerging Economies, 8(2), 97-118.

Anderson, J., Sutherland, D., \& Severe, S. (2015). An event study of home and host country patent generation in Chinese MNEs undertaking strategic asset acquisitions in developed markets. International Business Review, 24(5), 758-771.

Bartolini, S., Sarracino, F. (2015). The dark side of Chinese growth: Declining social capital and wellbeing in times of economic boom. World Development, 74, 333-351.

Bhanumurthy, N.R., \& Singh, P. (2013). Financial sector development and economic growth in Indian states. International Journal of Economic Policy in Emerging Economies, 6(1), 47-63.

Bozkurt, Ö.G., Erdem, C., \& Erollu, I. (2015). Identifying the factors affecting the economic growth of oil-producing countries. International Journal of Trade and Global Markets, 8(2), 97-111.

Caporale, G.M., \& Spagnolo, N. (2012). Stock market, economic growth and EU accession: Evidence from three CEECs. International Journal of Monetary Economics and Finance, 5(2), 183-191.

Castiglione, C., Infante, D., \& Smirnova, J. (2015). Environment and economic growth: Is the rule of law the go-between? The case of high-income countries. Energy, Sustainability and Society, 5(26). doi:10.1186/s13705-015-0054-8.

Chechina, O. S., \& Sultanova, A. V. (2016). Human Capital as a Key Factor of Economic Growth in Crisis. European Research Studies Journal, 19(2), 71-78.

Chen, J.-H., \& Chen, Y. (2015). New industry creation in less developed countries - the case of the Taiwanese flat panel display industry. Innovation: Management, Policy and Practice, 17(2), 250-265.

Choi, K.-H., \& Shin, S. (2015). Population aging, economic growth, and the social transmission of human capital: An analysis with an overlapping generations model. Economic Modelling, 50, 138-147.

Dowlah, C. (2015). International trade, competitive advantage and developing economies: How less developed countries are capturing global markets. Taylor and Francis Inc.

Dögl, C., \& Behnam, M. (2015). Environmentally sustainable development through stakeholder engagement in developed and emerging countries. Business Strategy and the Environment, 24(6), 583-600.

Dube, O. P., \& Sivakumar, M. (2015). Global environmental change and vulnerability of least developed countries to extreme events: Editorial on the special issue. Weather and Climate Extremes, 7, 2-7.

Fan, D., Cui, L., Li, Y., \& Zhu, C.J. (2015). Localized learning by emerging multinational enterprises in developed host countries: A fuzzy-set analysis of Chinese foreign direct investment in Australia. International Business Review, 25(1), 187-203.

Gehringer, A. (2014). Financial liberalisation, financial development and productivity growth: An overview. International Journal of Monetary Economics and Finance, 7(1), 40-65.

Gevorkyan, A., \& Semmler, W. (2016). Macroeconomic variables and the sovereign risk premia in EMU, non-EMU EU, and developed countries. Empirica, 43(1), 1-35.

González-Pernía, J. L., Peña-Legazkue, I. (2015). Export-oriented entrepreneurship and regional economic growth. Small Business Economics, 45(3), 505-522.

Jahfer, A., \& Inoue, T. (2014). Financial development, foreign direct investment and economic growth in 
Sri Lanka. International Journal of Economic Policy in Emerging Economies, 7(1), 77-93.

Jeníček, V., \& Grofová, Š. (2015). Least developed countries - the case of Burundi. Agricultural Economics, 61(5), 234-247.

Kandil, M. (2016). On the relationship between public and private spending in developing and developed countries. The Journal of International Trade and Economic Development, 25(2), 165-191.

Kuruppu, N., \& Willie, R. (2015). Barriers to reducing climate enhanced disaster risks in least developed country-small islands through anticipatory adaptation. Weather and Climate Extremes, 7, 72-83.

Lee, S., \& Oh, D.-W. (2015). Economic growth and the environment in China: Empirical evidence using prefecture level data. China Economic Review, 36, 870, 73-85.

Legatum Institute (2015). The 2014 Legatum Prosperity Index (2015). Available from http://media.prosperity.com/2014/pdf/publications/PI2014Brochure_WEB.pdf

Leonida, L., Maimone Ansaldo Patti, D., Marini, A., Navarra, P. (2015). Political competition and economic growth: A test of two tales. Economics Letters, 135, 96-99.-99.

NoNews (2015). Ranking of countries as to the rates of growth of GDP in 2014. Retrieved from http:// nonews.co/directory/lists/countries/gdp-temp

Odhiambo, N. M. (2015). Government expenditure and economic growth in South Africa: An empirical envestigation. Atlantic Economic Journal, 43(3), 393-406.

Pogosov, I.A. (2015). Factors of long-term economic growth: Scientific and technical progress and capital intensity of production. Studies on Russian Economic Development, 26(5), 423-433.

Popkova, E. G. Chechina, O. S., \& Sultanova, A. V. (2016). Structural and Logical Model of Contemporary Global Economic System. European Research Studies Journal, 19(2), 218-227.

Popkova, E. G., Yurev, V., Stepicheva, O., \& Denisov, N. (2015b). Transformation and concentration of intellectual capital as a factor of economic growth in the modern economy. Regional and Sectoral Economic Studies, 15(1), 53-60.

Regmi, K. D. (2015). The influence of supranational organizations on educational programme plan- ning in the least developed countries: The case of Nepal. Prospects, 45(4), 501-514.

Sarmiento Espinel, J. A., Silva Arias, A. C., Van Gameren, E. (2015). Quality differences of higher education and its determinants in a less-developed country. Journal of Higher Education Policy and Management, 37(2), 204-221.

Sekine, A. (2015). Effects of mineral-commodity price shocks on monetary policy in developed countries. Applied Economics, 47(31), 3332-3346.

Tsenkov, V. (2015). Crisis influences between developed and developing capital markets - The case of Central and Eastern European countries. Ikonomicheski Izsledvania, 24(3), 71-107.

Yes!travel (2015). Ranking of countries as to volume of direct foreign investments in 2014. Retrived from http://www.yestravel.ru/world/rating/stock_of_direct_foreign_investment_at_home_rank_order/

Zeira, J., \& Zoabi, H. (2015). Economic growth and sector dynamics. European Economic Review, 79, 1-15. 
